\title{
Potentials of Digital Archives: Topotheque of Smart Novel Vilijun - Case Study
}

\author{
Vlatka Lemić \\ Croatian State Archives \\ Marulićev trg 21, Zagreb, Hrvatska \\ vlemic@arhiv.hr \\ Josipa Mijoč \\ Faculty of Economics, University of Osijek \\ Trg Ljudevita Gaja 7, Osijek, Croatia \\ jmijoc@efos.hr \\ Nikolina Filipović \\ Faculty of Economics, University of Osijek \\ Trg Ljudevita Gaja 7, Osijek, Croatia \\ nfilipovic@efos.hr
}

\begin{abstract}
Summary
Observed from the "memory economy" perspective, digital archives of cultural heritage, besides the reliable memory function, have economic role in mapping local and global "cultural geography" as well. The mentioned economic role of digital archives is manifested in the long-term promotion of cultural heritage, thus turning archived content into the promoter of the cultural property itself, a place where it is located or with which the cultural property is connected with its origin, while a local community has economical, socials or historical links with this cultural property. The visibility of digital archives is closely related to the platform where the archival material is presented. This paper analyses archive collection of novel Vilijun as an example of open digital archives dedicated to one contemporary novel with heritage content. Topotheque digital platform uses interactive IT tools, it is based on a collaboration and engagement of heritage professionals, users and visitors, and descriptions of presented material go beyond the standardized rules of archival description. Topotheque Vilijun is private collection related to interactive novel Vilijun whose content promotes heritage. Promotion of the novel Vilijun is a new form of "memory economy" whose visibility, and thus promotional reach, transcends authors 'and publishers' activities. The presented content (the book - product of the publishing industry) through the reach and visibility of the Topotheque platform becomes a product of the cultural and creative industry whose promotion is happening and documenting on the long-term. It allows for long-time preservation and access to digital content and ensures it's promotion and is thus a "real" ar-
\end{abstract}


INFuture2017: Integrating ICT in Society

chive of the information society of the 21st century, mapping the spaces of "cultural geography".

Key words: cultural geography, digital archives, Topotheque, heritage, economy, novel Vilijun

\section{Introduction}

Memory is at the subject of interest of various sciences, ranging from humanities (history, art, philosophy), social sciences (sociology, anthropology, economy, information and communication), nature (medicine, chemistry, biology) till technical sciences (computer, robotics). Digital archives ${ }^{1}$ are connected with memory and technology and many global processes, as such centre of interest of archives, information managers, heritage professions and many other disciplines. One of comprehensive overview of relevant authors and topics regarding interconnections of archival science archives principles, ICT and digital era is given in Eric Ketelaar article Archives, memories and identities where authors concludes:

"Nevertheless archive(s) "as it is" have a unique quality and it is the archivist's calling to advocate that uniqueness benefiting many if not most processes of "meaning making" leading to identification and categorization; self-understanding and social location; commonality, connectedness, groupness. These identities are rooted in memories and these memories need inscription and need a space. Both inscription and space will increasingly be "located" "in the cloud" and maintained (in distributed custody) by individuals, groups, and memory institutions. Together they are actors in an ecology which comprises archives/records and other memory texts in a societal context..."

The memory of cultural heritage in the digital age is realized twice: on the Internet itself and in cultural monuments whose presentation is (not) realized on the Internet. Key role for this lays in archives, libraries and museums as memory institutions: they organise the [...] cultural and intellectual record. Their collections contain the memory of peoples, communities, institutions and individuals, the scientific and cultural heritage, and the products throughout time of our imagination, craft and learning. They join us to our ancestors and are our legacy to future generations. ${ }^{3}$

\footnotetext{
${ }^{1}$ Digital archives, digital libraries and digital collections are on the Internet often differed only by name in terms of digital repositories.

${ }^{2}$ Ketelaar, Eric. Archives, memories and identities (...), pp. 69

${ }^{3}$ Dempsey, Lorcan. Scientific, Industrial, and Cultural Heritage: A Shared Approach // Ariadne 22 (Tuesday, 21 December 1999). http://www.ariadne.ac.uk/issue22/dempsey
} 
The emergence of transnational public digital archival platforms (like Monasterium, Mapire, Topotheque) and digital archives such is Archives Portal Europe transcends some of the major controversies regarding trust in digitized memory, their content, and their source. At the same time, public digital archives prevail the network entropy where democracies in the advertising of data/information are crucial to phenomena such are: the difficult finding of relevant content, insufficient verifiability of relevant content and insufficient maintenance of advertised content. This paper will consider the assumptions and opportunities that arise from the presenting of cultural content in the public digital archive as well as its cost-effectiveness in the promotion of heritage and cultural memory.

\section{Archives in digital age}

Contemporary information society has influenced archives towards outreach, enhancing public knowledge on archival sources and encourages easy access to archives on the international level, while archival programs are connected with information society development and cultural heritage policy in general. Great number of projects under the "culture and history" framework are focused on programs and activities related to digital heritage, democratization of access to cultural heritage, social inclusion, information use and re-use, cultural industries and similar topics, including digital platforms, cultural networks and e-services. The best picture of $21^{\text {st }}$ century archives provides the Universal Declaration on Archives made by International Council on Archives, stating importance and necessity of archives, their diversity in recording every area of human activity, multiplicity of formats in which archives are created, the role of archivists in serving their societies, as well as collective responsibility of all society members in management of archives ${ }^{4}$. Declaration recognizes archives as unique and authentic whiteness of administrative, cultural and intellectual activities and as reflection of society evolution. As such, they are of vital importance for supporting business efficiency, accountability and transparency, for protecting citizens' rights, for establishing individual and collective memory, for understanding the past, and for documenting the present to guide future actions.

Contemporary archives are expected to be a public administration service regarding document management and protection and also to be providers of new services which would ensure better availability, visibility and presentation of archives and archival sources in the public by using new technologies. The international archival community through its documents and activities also emphasizes interaction and cooperation between archives, public administration and other professions and various public and private sectors. Accordingly, the activities of European archival community for decades are focused on co-operation and networking of archival institutions at all levels, development and im-

${ }^{4}$ ICA Universal declaration on Archives. http://www.ica.org/sites/default//files/UDA_June $\% 20$ 2012_web_EN.pdf 
plementation of professional standards, transfer of knowledge and creation of a common information infrastructure. ${ }^{5}$

\section{Cultural memory and memory economy}

The global era is characterized by information overwhelming and hence entropy as a result of semantic and informational controversy in finding content that is presenting online. Already Escarpit notes that the book as a product of the cultural and creative industries intended for mass selling differs books whose life on the book market primarily appears as a category of "short-term" creative product (best-sellers) to continue under certain circumstances its course towards a product that on the market lives as a "long-term book."

One of the prerequisites for a book, and its content, to live "in the long run" is the public visibility of the book - product of the creative industry. In terms of entropy of data published on the Internet, public digital archives can also contribute to the promotion of creative products in the long term, and thus the longevity of content that a given product represents. Although the purpose of the public digital archives is not primarily aimed at promoting the creative industries, their role can also be observed from this perspective, aligned with re-use of public sector information directions and outreach initiatives. Namely, the public archiving of the life span of a book that deals with heritage content, apart from publicly promoting publishing, at the same time builds up a map of cultural links that literary texts achieve - whether it is the representations of the literary text itself as part of the publishing promotion activities, or introducing heritage content described in the text. This opens the possibility to consider the public digital archives as a platform where "archival certified memory" contribute to the economy and social benefit of mapped areas, themes and archive material. Memory economy thus becomes a platform for long-term promotion of (cultural and/or creative) products, but for the first time in the history of literary engagement, it is possible to build a long-term memory at the time of its creation.

\section{Topotheque digital platform}

Topotheque is a digital platform - a collaborative online archives - providing public and free access to digitized historic sources from various community public and private collections. It is created by ICARUS ${ }^{7}$ in the framework of EU founded project co:op - "Community as Opportunity - the Creative Users' and Archives' Network" as a new opportunity of safeguarding and presenting less known, marginalised, and often not easily accessible historic documents.

\footnotetext{
${ }^{5}$ Lemić, V. Archives and society - what archives are, can and should be - Croatia case study (...), pp. 128

${ }^{6}$ Escarpit, Robert. The Book Revolution. London : Harrap, UNESCO, 1966, pp. 147

${ }^{7}$ ICARUS - International Centre for Archival Research. http://icar-us.eu/en/ 
International project co:op is financed through the Creative Europe program and it brings together 17 archival and academic institutions with more than 40 associated partners from all around Europe aiming at strengthening transnational cooperation between institutions and user groups. ${ }^{8}$ Following former project ENArC - "European Network on Archival Cooperation", co:op is going wider and deeper in strengthening and promoting the cooperation between archives and other institutions preserving our common cultural heritage, as well as, encouraging the active involvement of the general public. A variety of creative, pedagogical and didactic activities planned inside a four year schedule (including Topoteque, "Adventure in the archives" and "Bring your history days" programs, educational material for schools, historical workshops, scientific research etc.) are dedicated to the promotion of archival activities to the wider community, to fostering collaboration between the public and archives and to facilitating access to archival material by using the possibilities of the digital age.

Topotheque digital platform ${ }^{9}$ provides description, presentation and search of archival material by using interactive IT tools and description scheme compliant with ISAD $(G)$ standard which enables data transfer in other archival information systems. The administrational work within every Topotheque collection done by a registered topothequers, while visitors and users can also be engaged through answering questions online and, as guest-topothequers, uploading and indexing data (crowd work).

During the last two years more than 120 Topotheque collections all across Europe were published online and they helped visibility of its local communities on regional and national level, encouraged local programs and events (history and memory days) and helped the promotion of cultural and other manifestations and history specifics of local areas. Through them one can meet private family documents and photographs (like Bischoff family), monitor the changes in life and landscape of some small places (all around Europe) or famous sights (like Viennese Prater). All material and data on common Topotheque platform are delivering further to Europeana, thus building individual and local stories in shared European history ${ }^{10}$.

\section{Smart novel Vilijun Topotheque}

Smart novel Vilijun Topotheque was open to the public on 20 June 2017. It is private collection made by author of novel, consisting of various materials (archival records) connected with the novel: parts of the original text, illustrations in the novel, recordings made on book promotions, photos made on novels

\footnotetext{
${ }_{9}^{8}$ Project partners list is available at: https://coop.hypotheses.org/category/project-partners.

9 Topotheque is available at http://www.topotheque.eu/.

${ }^{10}$ Lemić, V. Mogućnosti suradnje arhiva i zajednice - co:op projekt // Glasnik arhiva i Arhivističkog udruženja BiH. 46 (2016), pp. 107-109
} 
presentations, media texts, literary theoretical reception, guest presentations at book fairs (Peking, Zagreb), footage of rehearsals the premiere performances of the novel Vilijun, recordings of the premiere performances of the nowel Vilijun and interviews with the author.

Vilijun is novel by author Jasna Horvat published in 2016 by Ljevak publishing company, labelled from critics as the first QR i.e. "smart" novel whose reading requires the use of a smartphone. In the annotation of the novel is the following description:

"The protagonists of Vilijun are Marco Polo and Kublai Khan in the year of their farewell. Marko Polo tells Kublai Khan about the cities on the Silk Road, and Khan is interested in Marko Polo stories to decide whether to allow him to return to his homeland. It is bond of two nomads and two cultures within which Marko Polo also describes numerous other cultures he met and got to know on the Silk Road. It is a novel about nomadism thought and traveller, but also about trust, friendship and loyalty." ${ }^{11}$

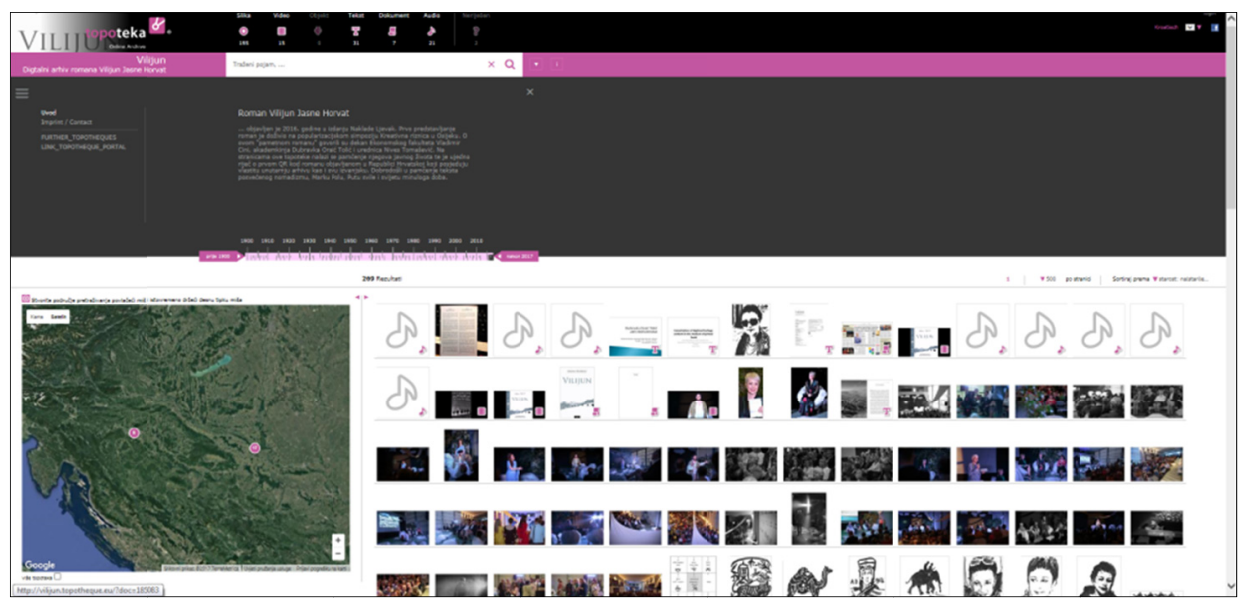

Figure 1. Topothetheque Vilijun (http://vilijun.topotheque.eu/)

Topotheque Vilijun is a new step in the interactivity of this text, which allows everyone paper and web travel by the Silk Road stations - it is a digital archive of one novel, who is also a holder of heritage memories. Topotheque Vilijun in many ways is unique archive - it keeps various records (presentations, promotions, newspaper articles, theatrical plays, performances at book fairs, thematic talks, published cultural and literary criticisms, scientific papers) which document the life of this novel; it consists of all types of media (documents, photos,

${ }^{11}$ Knjižara Ljevak, http://www.ljevak.hr/knjige/knjiga-20935 
$\mathrm{AV}$ records etc) and it encompasses existing, as well as yet non created documents that we do not know when will be make, how they will look like and what kind of ideas will trigger them. As live, timeless public archives that links the story and the characters, readers, scientists, artists, users and all those whose paths are connected with them at a particular moment -through the theme and life of the novel Vilijun - Topotheque Vilijun is an archive of the information global society of the 21 st century and at the same time a new form of promotion of heritage themes and the very novel itself as a product of the creative industry.

\section{Multimedia novel}

Novel Vilijun is an example of contemporary literary text that links the media of printed books with the Internet - a global digital media. It is the first published QR novel in Croatia and also the first novel that presents heritage themes in an innovative way. In her Afterwords in the print novel, Dubravka Oraić-Tolić states the following:

" ... A new shift in the work of Jasna Horvat occurred in the book Vilijun (2016). It is a multifaceted novel-toy. This is, on the one hand, conscious, planned, organized and thematic re-conceived permutation of the Vilikon novel. On the other hand, it is a "smart book" (author's self-concept) that is symbolically and truly linked to new technologies, mobile phones and the world of the Internet. In the first, textual layer of a novel, the author is playing with her own novel Vilikon and his reconceptualization. In the second, para-textual layer (QR-codes scattered in the novel) she offers the reader an opportunity for endless games and thus creates an interactive hypertext - a book toy." ${ }^{12}$

In her critical review of the novel, Oraić-Tolić notes that this innovative way of literary expression give the possibilities of multiple readings, and that Vilijun is "first Croatian interactive hypertext novel with a million of possibilities of textual, visual and network nomadism" and illustrates this with two QR codes from Vilijun which are results of the author's work, i.e. the first of them came about one year before the publication of the novel, and the second came about at the first presentation of the novel Vilijun.

Both QR codes perform (musical and acting) poem Million, which is part of the novel Vilijun. In addition, both contents encrypted with these QR codes are in some way archival documents because they are part of the author's private collection and are directly related to the creation and the presentation of the novel of which they are an integral part. In this way, novel Vilijun can be seen as an

12 Oraić-Tolić, Dubravka. Ars Horvatiana. U: Horvat, Jasna. Vilijun. Zagreb: Naklada Ljevak, 2016, pp. 211. 
own archive collection, thus opening up the question of the documentary capacity of the novel itself. ${ }^{13}$

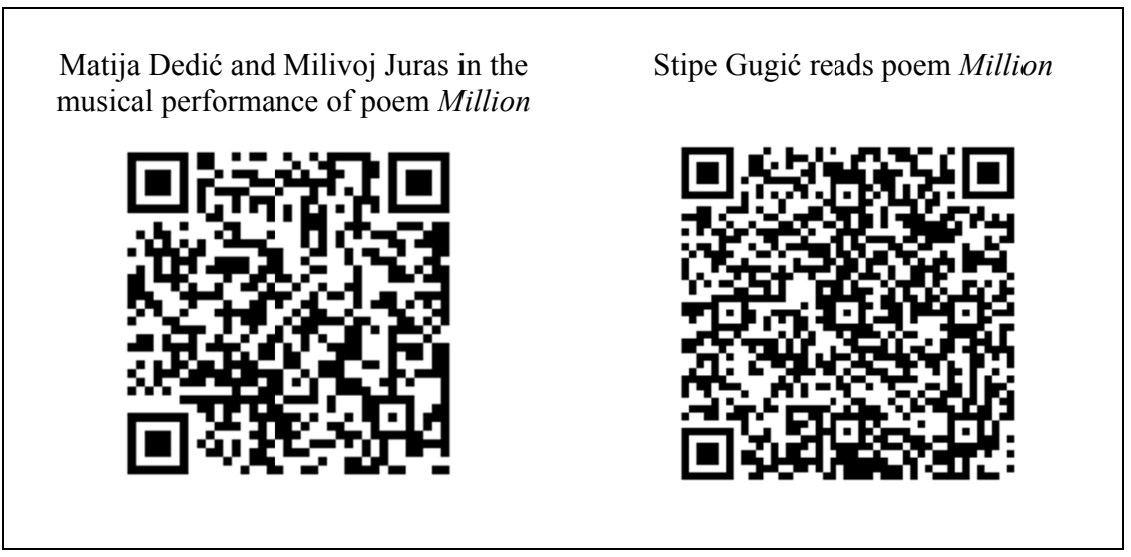

Figure 2. QR codes from Vilijun novel

\section{Novel - digital archive of heritage themes}

If we accept the possibility that contemporary literary text with the mediation of QR codes has capacity of digital archiving of its own content, the question is whether such a record is able to promote topics whose information is relevant as a basis for non-fictional considerations. Since in Vilijun novel there is a "nonfictive, lexical part" that "fully functions in accordance with the principles of lexicon as a lexicographic type of text"14, Table 1 lists the lexicographic sections that the novel brings forth.

As it can be seen from the allegation of the lemma shown in Table 1, the novel Vilijun offers readers information about cities on the Silk Road, cities of importance to the life of Marco Polo (Field 2), the land and sea route of Silk Road, selected cities on the Silk Road, the products traded in the 13th century (Field 6)and about the four symbols of the identity of Croatian culture (Field 4). The lexicographic approach to the formulation of literary text and the additional presentation of documents with the help of QR codes allows concluding that the Vilijun printed novel implied the digital archiving of heritage themes.

\footnotetext{
${ }^{13}$ Ibid, pp. 217

${ }^{14}$ Kos-Lajtman, Andrijana. Poetika oblika. Zagreb: Naklada Ljevak, 2016, pp. 199. 
V. Lemić, J. Mijoč, N. Filipović, Potentials of digital archives ...

Table 1: Novel Vilijun lemmas

\begin{tabular}{|c|c|c|}
\hline $\begin{array}{c}\text { First row of magic square of } \\
\text { number } 12\end{array}$ & $\begin{array}{l}\text { Second row of magic } \\
\text { square of number } 12\end{array}$ & $\begin{array}{c}\text { Third row of magic } \\
\text { square of number } 12\end{array}$ \\
\hline FIELD 3 & FIELD 8 & FIELD 1 \\
\hline $\begin{array}{l}\text { (1) Korčula } \\
\text { (2) Šibenik - City of Krešimir } \\
\text { (3) Venetia }\end{array}$ & $\begin{array}{ll}\text { (1) } & \text { Jerusalem } \\
\text { (2) } & \text { Mosul } \\
\text { (3) } & \text { Bagdad } \\
\text { (4) } & \text { Samarkand } \\
\text { (5) } & \text { Baktra } \\
\text { (6) } & \text { Kashgar } \\
\text { (7) } & \text { Lanzhou } \\
\text { (8) } & \text { Karakorum } \\
\end{array}$ & $\begin{array}{l}\text { (1) The song about the } \\
\text { names of cities on the } \\
\text { Silk Road }\end{array}$ \\
\hline FIELD 2 & FIELD 4 & FIELD 6 \\
\hline $\begin{array}{l}\text { (1) About land route of the Silk } \\
\text { Road - the way to the East } \\
\text { (2) About sea route of the Silk } \\
\text { Road - the way to the West }\end{array}$ & $\begin{array}{l}\text { (2) Croatian coat of arm } \\
\text { (Kockovlje) } \\
\text { (3) Early-Croatian three- } \\
\text { strand patern (Troplet) } \\
\text { (4) Name Croat (Hrvat) } \\
\text { (5) Glagolitic script } \\
\text { (Glagoljica) }\end{array}$ & $\begin{array}{l}\text { (1) Tea and spices } \\
\text { (2) Silk } \\
\text { (3) Porcelain } \\
\text { (4) Cashmere } \\
\text { (5) Paper } \\
\text { (6) Compass }\end{array}$ \\
\hline FIELD 7 & $\begin{array}{l}\text { FIELD 0 } \\
\end{array}$ & FIELD 5 \\
\hline $\begin{array}{ll}\text { (1) } & \text { Bagan } \\
\text { (2) } & \text { Chengdu } \\
\text { (3) } & \text { Camblau } \\
\text { (4) } & \text { Hormuz } \\
\text { (5) } & \text { Arbil } \\
\text { (6) } & \text { Trabzon } \\
\text { (7) } & \text { Carigrad }\end{array}$ & $\begin{array}{l}\text { About not mentioning } \\
\text { Marko's return to the } \\
\text { Kingdom of Croatia. }\end{array}$ & $\begin{array}{ll}\text { (1) } & \text { Golden plate } \\
\text { (2) } & \text { Salt } \\
\text { (3) } & \text { Fairies } \\
& \text { notifications } \\
\text { (4) } & \text { World map } \\
\text { (5) } & \text { Million }\end{array}$ \\
\hline
\end{tabular}

\section{Double archiving in Topotheque Vilijun}

Archival activities, mostly classified as part of the cultural and creative industries sector and often encountered within the GLAM acronym, were greatly influenced by the digital age, like other cultural and creative industries. Thus, it becomes part of an "open society" and affects the understanding and use of terms such as "access" and "re-use". Ideas of openness, networking and integration in building of common information Internet infrastructure are part of many EU strategies, reports, summaries, programming documents and initiatives, like in the following words: "Especially the aspects 'access' and 'reuse' of digital resources are strongly connected with the sustainability of the digital resources, because if the digital resources are not preserved, this naturally means an end to all access and reuse. This problem begins with the well-known phenomenon of a broken link if a website is no longer maintained and no more of use to verify information. The common denominator 'digital sustainability' (also long-term preservation or digital curation) describes a span of activities that more or less encompass the whole research (data) lifecycle and exceeds the narrow sense of archiving in general linguistic usage. The term archiving means to archives, museums, and libraries more than permanent storage on a medium, it encom- 
passes the notion of ensuring long-term access and therefore includes the need to preserve modes of reuse and retaining the interpretability of the digital resources ${ }^{15}$. This is a collective task, which includes many stakeholders, from researchers to digital preservation specialists."16

Apart from the above, it can be seen that the contents presented in public digital archives (such is Topotheque) also have other advantages, including public visibility of the presented content and overcoming the problem of semantic web. Considering the basic role of Topotetheque in linking the places of creation of archival records with the main theme of Topotheque collection, it is possible to conclude that Topotheque realizes the mapping of "cultural geography" and that the "archive map", along with the effects of long-term memory, also promotes archived content on long time.

According to the example of Topotheque Vilijun, it is noticed that double archiving of heritage content was achieved: a) primarily in the creative industry product itself (novel Vilijun) and based on the author's research of historical and cultural sources, and then b) in the digital archive of Topotetheque Vilijun by advertising scientific and professional studies of the novel Vilijun as well as documents that certify the market and social life of this text.

\section{Conclusion}

Topotheque Vilijun is real example how archives can "come out of a box". It is open and borderless in all senses - by its scope (type and quantity of records), content, use and opportunities. It also shows how digital archives can actively link heritage, education, community, creative industries and other potentials, be resource and inspiration for creation of new information and cultural products and services, speed up and facilitate sharing, gathering, presentation, research, publishing and documenting sources and making it accessible to the whole world. This is what archives should be - link between past and future.

\footnotetext{
${ }^{15}$ See: Neuroth et al. (nestor Handbuch), 2010, Kap. (title) 1:3

${ }^{16}$ Wuttke et al. (...), pp. 22
} 
V. Lemić, J. Mijoč, N. Filipović, Potentials of digital archives ...

\section{References}

Dempsey, Lorcan. Scientific, Industrial, and Cultural Heritage: A Shared Approach // Ariadne 22 (Tuesday, 21 December 1999). http://www.ariadne.ac.uk/issue22/dempsey

Escarpit, Robert. The Book Revolution. London : Harrap, UNESCO, 1966.

Horvat, Jasna. Vilijun. Zagreb : Naklada Ljevak, 2016

H. Neuroth et al., Hrsg. 2010. NESTOR-Handbuch: Eine kleine Enzyklopädie der digitalen Langzeitarchivierung. (Version 2.3.) Göttingen. Kap.4:13, Kap.4:15- Kap.4:16. Online: http://nbnresolving.de/urn/ resolver.pl?urn:nbn:de:0008-2010071949

ICA Universal declaration on Archives. http://www.ica.org/sites/default//files/UDA June $\% 20$ 2012_web_EN.pdf

ICARUS - International Centre for Archival Research. http://icar-us.eu/en/

Ketelaar, Eric. Archives, memories and identities // Records, archives and memory : selected papers from the Conference and School on records, archives and memory studies, University of Zadar, Croatia, May 2013 / Willer, M.; Gilliland, A.J.; Tomić, M. (ed.). Zadar : Sveučilište u Zadru, 2015, str 47-76

Kos-Lajtman, Andrijana. Poetika oblika. Zagreb : Naklada Ljevak, 2016

Knjižara Ljevak. http://www.ljevak.hr/knjige/knjiga-20935

Leathem, Camilla; Adrian, Dominik,. Survey and Analysis of Basic Social Science and Humanities Research at the Science Academies and Related Research Organisations of Europe. Berlin: Union of the German Academies of Sciences and Humanities, 2015. http://www.akademienunion.de/fileadmin/redaktion/user_upload/Publikationen/Proj ectReport_SASSH_2015.pdf.

Lemić, V. Mogućnosti suradnje arhiva i zajednice - co:op projekt // Glasnik arhiva i Arhivističkog udruženja BiH. 46 (2016), str. 99-110

Lemić, V. Archives and society - what archives are, can and should be - Croatia case study // Proceeding book with peer review / Symposium Archives in the Service of People - People in the Service of archives in conjuction with 5th International Scientific Conference All About People: Interdisciplinarity, Transnationality and Building Bridges, Maribor, 10.-11.3.2017. / Filej, B.; Klasinc, P.P. (ur.). Maribor: Alma Mater Europea - ECM, 2017, str. 128-136

Oraić-Tolić, Dubravka. Ars Horvatiana. U: Horvat, Jasna. Vilijun. Zagreb: Naklada Ljevak, 2016, str. 206-223

Topotheque. http://www.topotheque.eu/

Topothetheque Vilijun. http://vilijun.topotheque.eu/

Wuttke, Ulrike; Ott, Carolin; Adrian, Dominik; Worthington, Simon. AGATE: Concept for a European Academies Internet Gateway for the Humanities and Social Sciences, 2017, http://doi.org/10.5281/zenodo.815916 